\title{
Evaluasi pelepasan Trichogramma spp. untuk pengendalian penggerek pucuk dan batang tebu
}

\author{
Evaluation of Trichogramma spp. releases for \\ controlling sugarcane top-and stalk borers
}

\author{
Nurindah*, Dwi Adi Sunarto, Sujak \\ Balai Penelitian Tanaman Pemanis dan Serat \\ Jalan Raya Karangploso, Kotak Pos 199, Malang 65152 \\ (diterima Februari 2016, disetujui Juli 2016)
}

\begin{abstract}
ABSTRAK
Evaluasi keberhasilan dan efektivitas pengendalian hayati menggunakan Trichogramma spp. untuk mengendalikan penggerek pucuk dan batang tebu belum pernah dilakukan secara intensif. Penelitian ini bertujuan untuk mengevaluasi teknik pengendalian kompleks penggerek tebu dengan pelepasan Trichogramma spp. Evaluasi dilakukan dengan pendekatan pengujian keragaan parasitoid telur melalui penghitungan laju reproduksi dan kemampuan parasitisasi parasitoid pada telur Corcyra cephalonica (Stainton), telur inang yang biasa digunakan dalam produksi massal Trichogramma spp. Observasi lapangan dilakukan untuk mengetahui tingkat parasitisasi telur penggerek pucuk dan batang tebu pada pertanaman tebu dengan dan tanpa pelepasan Trichogramma spp. Observasi ini dilakukan dengan mengumpulkan telur penggerek pucuk dan penggerek batang tebu dari kedua lahan tersebut dan diamati tingkat parasitisasinya. Hasil evaluasi menunjukkan bahwa pelepasan Trichogramma chilonis Ishii atau Trichogramma japonicum Ashmead tidak efektif memarasit telur S. excerptalis atau Chilo spp. Parasitisasi $100 \%$ telur $S$. excerptalis dan $77 \%$ telur Chilo spp. disebabkan oleh Telenomus sp. Keragaan T. japonicum yang dilepas menunjukkan kebugaran yang rendah. Oleh karena itu, pelepasan Trichogramma spp. untuk mengendalikan kompleks penggerek tebu di Indonesia perlu dipertimbangkan lagi dengan mempertimbangkan spesies parasitoid yang dilepas dan teknik pelepasannya untuk memperoleh pengendalian hayati yang sukses.
\end{abstract}

Kata kunci: Chilo sp., Telenomus, Trichogramma, Scirpophaga excerptalis

\begin{abstract}
The success and effectiveness evaluation of Trichogramma releases for controlling sugarcane top borer (Scirpophaga excerptalis (Walker)) and stalk borers (Chilo spp.) have not been intensively evaluated. This research was aimed to evaluate the control technique of sugarcane borer complex by releasing Trichogramma spp. The evaluation approach was performance tests of the parasitoid fitness through determination of reproductive rate and parasitism capacity of the parasitoids. Field observations were also done to obtain the borers' egg parasitism level in Trichogramma released and unreleased sugarcane fields. The observation was done by collecting the borers' eggs in such fields and egg parasitism level was recorded. Results showed that releases of Trichogramma chilonis Ishii or Trichogramma japonicum Ashmead were not effectively caused egg parasitism on S. excerptalis or Chilo spp. A hundred \% parasitism of S. excerptalis eggs and
\end{abstract}


77\% parasitism of Chilo spp. were caused by Telenomus sp. T. chilonis parasitized only Chilo spp. Reproductive performance of T. japonicum indicated a low reproduction capacity. Mass releases of Trichogramma spp. for controlling the sugarcane borers' complex in Indonesia has to be reconsidered by taking into account the species and release technique to obtain a successful biocontrol of sugarcane borers' complex.

Key words: Scirpophaga excerptalis, Chilo sp., Trichogramma, Telenomus

\section{PENDAHULUAN}

Serangan kompleks penggerek tebu, yaitu penggerek pucuk dan penggerek batang tebu masih merupakan faktor penghambat produksi karena menyebabkan kerugian hingga lebih dari 20\% (Hadisaputro 2011; Purwono 2012). Pramono et al. (2009) melaporkan bahwa di pertanaman yang dikelola PG Kembang Mayang, Lampung, intensitas serangan penggerek pucuk mencapai 6-49\%, penggerek batang mencapai $9-18 \%$, dan jenis penggerek batang bergaris lebih dominan dibandingkan dengan penggerek batang berkilat, serta distribusi serangannya merata di seluruh kebun. Tingkat serangan kompleks penggerek tebu $25 \%, 50 \%$, dan $75 \%$ menyebabkan kehilangan hasil masing-masing 9\%, 19\%, dan 31\% (Afghan et al. 2006). Serangan kompleks penggerek tidak hanya menurunkan produksi tebu, tetapi juga berpengaruh terhadap kandungan gula dalam batang tebu. Naqvi et al. (1978) melaporkan terdapat korelasi negatif antara intensitas serangan penggerek dan kandungan sukrosa batang tebu, dan penurunan sukrosa hingga mencapai lebih dari $10 \%$.

Kompleks penggerek tebu ini juga merupakan ancaman utama dalam budi daya tebu di negaranegara penghasil gula, seperti Pakistan (Bhati et al. 2008), Brazil (Goebel \& Sallam 2011), Lousiana, AS (Reagan 2001). Di Thailand, kompleks penggerek tanaman tebu terdiri atas 5 spesies, yaitu Chilo infuscatellus Snellen, Chilo sacchariphagus (Bojer), Chilo tumidicostalis (Hampson), Sesamia inferens (Walker), dan Scirpophaga excerptalis (Walker) (Suasa-ard 2010). Hasil survei tim ACIAR dan P3GI di Jawa pada 2008-2009 didapatkan bahwa kompleks penggerek tebu terdiri atas 5 spesies, yaitu Chilo auricilius Dudgeon, C. sacchariphagus, S. excerptalis, $S$. inferens, dan Tetramoera schistaceana (Snellen) (Sallam et al. 2010). Chilo spp. merupakan penggerek batang yang banyak ditemukan di 108 pertanaman, sedangkan $S$. excerptalis merupakan penggerek pucuk yang menyerang tanaman muda maupun tua, dan infestasinya lebih tinggi pada pertanaman tebu yang dikelola pabrik gula (HGU) daripada tebu rakyat (Magarey et al. 2010).

Pengendalian penggerek pucuk dan batang tebu pada umumnya secara hayati dengan teknik pelepasan massal parasitoid telur, terutama Trichogramma chilonis Ishii. Penggunaan insektisida untuk pengendalian penggerek tebu tidak direkomendasikan di Mauritius (Soma \& Ganeshan 1998), tetapi penggunaan parasitoid telur Trichogramma australicum Girault dan parasitoid larva Cotesia flavipes (Cameron) lebih umum digunakan (Ganeshan \& Rajabalee 1997). Pelepasan T. chilonis pada 100 titik pelepasan dapat menekan infestasi C. sacchariphagus sehingga produksi tebu meningkat 23\% (Marquier et al. 2008). Pelepasan T. chilonis sebanyak 12.000 parasitoid/acre per bulan selama 5 bulan (Apil-September) dapat menekan intensitas serangan kompleks penggerek sebesar 35\% dan $45 \%$, serta meningkatkan produksi $19 \%$ dan $14 \%$, masing-masing pada tanaman baru dan ratoon di Pakistan (Gul et al. 2008). Pelepasan $T$. chilonis sebanyak 8 kali dengan dosis $8-10$ pias/ pelepasan/acre dapat meningkatkan parasitisasi telur penggerek hingga $80 \%$ di pertanaman tebu Filipina (Javier \& Gonzales 2000). Di Thailand dilaporkan bahwa parasitoid telur T. chilotraeae Nagaraja \& Nagarkatti dan parasitoid larva $C$. flavipes merupakan agens hayati yang digunakan dalam program pengendalian kompleks penggerek tebu (Suasa-ard 2010), sedangkan di Brazil, Telenomus alecto Crawford dan Trichogramma galloi Zucchi dipelajari dan dimanfaatkan sebagai agens pengendali penggerek tebu Diatraea flavipennella (Box) (Dias-Pini et al. 2012).

Pengendalian kompleks penggerek tanaman tebu di Indonesia pada umumnya dilakukan dengan menggunakan varietas tahan, pelepasan parasitoid telur, dan penggunaan insektisida 
berbahan aktif karbofuran, profenofos, fipronil, dan metidation (Achadian et al. 2011). Sedikitnya ada 4 spesies parasitoid telur yang digunakan dalam program pengendalian kompleks penggerek tebu, yaitu T. chilonis, T. japonicum Ashmead, T. australicum, dan T. nanum (Zehnt.) (Box 1953; Mohyuddin 1992). Pelepasan massal T. chilonis dilaporkan dapat menyebabkan parasitisasi telur penggerek batang C. infuscatelus mencapai 98\% (Mohyuddin 1992). Pelepasan dilakukan dengan melepas50 pias (@2000 ekor)per hektar dilepas setiap minggu pada waktu umur 1-4 bulan atau 16 kali pelepasan (Achadian et al. 2011). Teknik pelepasan ini belum pernah dievaluasi hasilnya dalam menekan populasi penggerek ataupun kerusakan yang ditimbulkannya. Pengendalian penggerek pucuk pada pertanaman GMP Lampung dilakukan dengan pelepasan dan konservasi musuh alami, aplikasi insektisida tanah, serta pengendalian secara mekanis menggunakan perangkap. Walaupun demikian, infestasi penggerek pucuk pada 10 tahun terakhir mencapai $18,8 \%$ pada varietas yang rentan, seperti TC4 (Saeroji et al. 2010).

Penggunaan parasitoid telur dari genus Trichogramma telah banyak dilakukan untuk pengendalian hama dari Ordo Lepidoptera pada tanaman pangan maupun perkebunan. Kebehasilan parasitisasi inang melibatkan faktor-faktor yang berpengaruh dalam inteaksi tritrofik (hubungan parasitoid-inang-tanaman inang). Adanya inteaksi tritrofik ini mengakibatkan satu spesies parasitoid efektif sebagai agens hayati untuk spesies inang tertentu yang berasosiasi dengan tanaman inang tertentu (spesifik spesies). Walaupun Trichogramma spp. diklaim sebagai parasitoid polifag, penggunaan spesies parasitoid yang tidak sesuai dengan inang sasaran pada tanaman tebu berakibat pada pengendalian yang tidak efektif. Oleh karena itu, penelitian ini bertujuan untuk mengevaluasi efektivitas spesies Trichogramma yang digunakan dalam program pengendalian kompleks penggerek tebu. Evaluasi teknik pengendalian ini difokuskan pada evaluasi keragaan agens hayati yang digunakan dalam pengendalian dan observasi tingkat parasitisasi telur di lapangan.

\section{BAHAN DAN METODE}

Evaluasi teknik pengendalian kompleks penggerek tebu dilakukan pada Januari-September 2013. Evaluasi ini meliputi kegiatan observasi lapangan untuk mengamati tingkat parasitisasi telur penggerek pucuk dan batang tebu pada pertanaman tebu yang mendapatkan perlakuan pelepasan dan tanpa pelepasan Trichogramma spp., dan pengamatan keragaan biologi Trichogramma spp. yang diperbanyak dan digunakan dalam pelepasan massal.

\section{Observasi tingkat parasitisasi telur penggerek pucuk dan batang tebu}

Observasi ini dilakukan dengan mengumpulkan telur $S$. excerptalis dan Chilo spp. pada pertanaman tebu dengan pelepasan dan tanpa pelepasan Trichogramma spp. dan diamati tingkat parasitisasinya, serta identifiksi parasitoid yang muncul. Observasi dilakukan pada pertanaman tebu rakyat dan tebu yang dikelola oleh perusahaan besar di Lampung Tengah, Pati, Malang, dan Situbondo (Tabel 1).

Pada setiap lokasi dilakukan pengumpulan telur kedua jenis penggerek yang diletakkan secara

Tabel 1. Koordinat lokasi observasi pasitisasi pada telur Scirpophaga excerptalis dan Chilo spp. pada tanaman tebu dengan dan tanpa pelepasan Trichogramma chilonis dan T. japonicum

\begin{tabular}{lll}
\hline Lokasi & \multicolumn{1}{c}{ Koordinat } & \multicolumn{1}{c}{ Status pertanaman } \\
\hline $\begin{array}{l}\text { Terusan Nunyai, Gunung Batin, } \\
\text { Lampung Tengah }\end{array}$ & 4.702166 LS; 105.242885 BT & Dengan pelepasan T. chilonis $^{1}$ \\
Muktiharjo, Margorejo, Pati & 6.733828 LS; 111.013254 BT & Tanpa pelepasan Trichogramma spp. \\
Pakis, Malang & 7.96754 LS; 112.703294 BT & Tanpa pelepasan Trichogramma spp. \\
Banyuputih, Situbondo & 7.857708 LS; 114.381682 BT & Tanpa pelepasan Trichogramma spp. \\
Asembagus, Situbondo & 7.888023 LS; 114.215273 BT & Dengan pelepasan T. japonicum \\
\hline
\end{tabular}

${ }^{1}$ Pengumpulan telur dilakukan 5 hari setelah dilakukan pelepasan parasitoid. 
alami pada lahan seluas 0,5 ha yang terdapat pada suatu hamparan pertanaman tebu seluas 3-5 ha (luas samping 10-60\% luas hamparan). Pengumpulan telur penggerek pada lahan yang dilepas Trichogramma dilakukan 3-5 hari setelah pelepasan. Telur-telur yang terkumpul disimpan dalam tabung gelas (Ø $15 \mathrm{~mm}$, panjang $80 \mathrm{~mm}$ ) secara terpisah, diberi label, dan kemudian dipelihara pada ruangan dengan suhu $27 \pm 2{ }^{\circ} \mathrm{C}$ dan $\mathrm{RH}=70-80 \%$. Jumlah parasitoid yang mucul dan jumlah telur yang menetas menjadi larva dicatat untuk menghitung tingkat parasitisasi. Parasitoid yang muncul diidentifikasi.

Observasi di lapangan juga dilakukan pengamatan tingkat kerusakan batang tebu oleh penggerek batang dengan menghitung jumlah ruas yang terserang. Ruas tebu yang terserang ditandai dengan adanya lubang pada batang tebu yang merupakan lubang yang dibuat larva sebagai jalan keluarnya dari batang untuk berpupa. Konfirmasi ruas terserang yang teramati dilakukan dengan membelah batang tebu. Ruas yang terserang ditandai dengan adanya gerekan dalam batang tebu.

\section{Keragaan reproduksi dan kebugaran Tricho- gramma spp. yang digunakan dalam pelepasan massal}

Pelepasan massal Trichogramma spp. pada umumnya dilakukan pada pertanaman tebu yang dikelola oleh perusahan besar. Oleh karena itu, pada umumnya perusahaan besar mempunyai unit produksi Trichogramma spp. Produksi massal Tichogramma spp. pada umumnya menggunakan teknik yang dikembangkan oleh Pramono (1983) dan Achadian (2011) dengan menggunakan inang pengganti, yaitu telur ngengat beras Corcyra cephalonica Stainton. Pada umumnya Trichogramma spp. yang dihasilkan oleh unit-unit produksi ini lebih dari 10 generasi diperbanyak dengan menggunakan inang pengganti.

Evaluasi keragaan reproduksi dan kebugaran Trichogramma spp. dilakukakan dengan mengambil sampel Trichogramma spp. dari unit-unit produksi di PG Gunung Madu Plantation(Lampung Tengah-1 spesies), PG Trangkil (Pati-4 spesies), PG Kebon Agung (Malang-1 spesies), dan PG Asembagus (Situbondo-1 spesies). Pengambilan sampel dilakukan pada waktu parasitoid telur pada stadium pupa, masing-masing sebanyak 1200 1500 pupa. Pupa parasitoid tersebut ditempelkan pada kertas berukuran $10 \mathrm{~mm} \times 10 \mathrm{~mm}$ (disebut pias parasitoid). Sampel berupa pias Trichogramma spp. tersebut kemudian dimasukkan dalam tabung gelas (Ø $15 \mathrm{~mm}$, panjang $80 \mathrm{~mm}$ ) dan disimpan dalam ruangan bersuhu $27 \pm 2{ }^{\circ} \mathrm{C}$ dan $\mathrm{RH}=70$ $80 \%$. Parasitoid yang muncul digunakan dalam evaluasi dan diperbanyak dengan menggunakan telur C. cephalonica yang diproduksi dengan teknik yang dikembangkan oleh Nurindah (2004).

Evaluasi keragaan biologis parasitoid difokuskan pada uji kapasitas reproduksi yang dapat digunakan sebagai indikasi efektivitas parasitoid sebagai agens hayati (Liu \& Smith 2000). Uji kapasitas reproduksi dilakukan dengan menganalisa laju pertumbuhan intrinsik dengan metode Birch (1948) dan Chi (1988).

Pada evaluasi ini digunakan 10 betina parasitoid yang baru muncul dari masing-masing sampel. Uji kapasitas reproduksi Trichogramma spp. dilakukan dengan menggunakan telur $C$. cephalonica sebagai inangnya. Sekelompok telur inang ditawarkan pada satu individu betina parasitoid dalam tabung gelas $(\varnothing 15 \mathrm{~mm}$, panjang $80 \mathrm{~mm}$ ) selama 24 jam, kemudian diganti sekelompok telur baru yang dipaparkan pada parasitoid selama 24 jam. Pemaparan telur inang ini dilakukan terus hingga parasitoid mati. Lama hidup setiap individu parasitoid dicatat. Selain itu juga, dihitung selang umur (x) betina, jumlah individu betina yang hidup pada umur $\mathrm{x}\left(1_{\mathrm{x}}\right)$, jumlah offspring betina pada umur induk $\mathrm{x}\left(\mathrm{m}_{\mathrm{x}}\right)$. Laju pertumbuhan intrinsik (r), laju reproduksi bersih $\left(R_{o}\right)$, rata-rata periode per generasi $(T)$, dan laju pertumbuhan terbatas $(\lambda)$ (Tabel 2).

\section{HASIL}

\section{Tingkat parasitisasi telur penggerek pucuk dan batang tebu}

Telur Chilo spp. pada pertanaman tebu dengan dan tanpa pelepasan Trichogramma spp. pada umumnya diparasit oleh dua spesies parasitoid telur, yaitu T. chilonis dan Telenomus sp. (Tabel 3). Kedua spesies ini tidak ditemukan memarasit satu kelompok telur yang sama. Tingkat parasitisasi oleh Telenomus sp. lebih tinggi dibandingkan 
Tabel 2. Parameter dan penghitungan laju pertumbuhan intrinsik

\begin{tabular}{ll}
\hline Parameter & Keterangan \\
\hline $\mathrm{x}$ & Selang umur induk parasitoid (hari). \\
$\mathrm{l}_{\mathrm{x}}$ & Proporsi induk yang bertahan hidup dari peletakan telur pertama sampai hari-x. \\
$\mathrm{m}_{\mathrm{x}}$ & Jumlah progeni betina yang dihasilkan per induk pada umur-x. \\
$\mathrm{R}=\Sigma 1_{\mathrm{x}} \cdot \mathrm{m}_{\mathrm{x}}$ & Laju reproduksi bersih (laju perkembangan populasi parasitoid per induk per generasi. \\
$\mathrm{T}=\Sigma 1_{\mathrm{x}} \cdot \mathrm{m}_{\mathrm{x}} \cdot \mathrm{x} / \mathrm{R}_{\mathrm{o}}$ & Waktu yang diperlukan parasitoid untuk menghasilkan satu generasi. \\
$\mathrm{r}=\log _{\mathrm{e}} \cdot \mathrm{R} / \mathrm{T}$ & Kapasitas pertambahan populasi parasitoid. \\
$\lambda=\mathrm{r}^{\mathrm{r}}\left(\operatorname{antilog} \mathrm{e}^{\mathrm{r}}\right)$ & Laju pertambahan parasitoid per hari. \\
\hline
\end{tabular}

Tabel 3. Tingkat parasitisasi telur penggerek pucuk dan penggerek batang tebu pada pertanaman tebu dengan pelepasan dan tanpa pelepasan Trichogramma spp. di beberapa lokasi

\begin{tabular}{|c|c|c|c|}
\hline Lokasi & Spesies penggerek tebu & Spesies parasitoid & $\begin{array}{c}\text { Tingkat parasitisasi telur } \\
\qquad(\%)\end{array}$ \\
\hline $\begin{array}{l}\text { Lampung } \\
\text { Tengah }^{1}\end{array}$ & Chilo spp. ( $\mathrm{n}=14$ kelompok telur) & $\begin{array}{l}\text { T. chilonis } \\
\text { Telenomus sp. }\end{array}$ & $\begin{array}{l}43 \\
57\end{array}$ \\
\hline Situbondo $^{2}$ & Chilo spp. $(\mathrm{n}=136$ kelompok telur) & $\begin{array}{l}\text { T. chilonis } \\
\text { Telenomus sp. }\end{array}$ & $\begin{array}{l}27 \\
53\end{array}$ \\
\hline Situbondo $^{3}$ & $\begin{array}{l}\text { Chilo spp. ( } \mathrm{n}=3 \text { kelompok telur) } \\
\text { Scirpophaga excerptalis (3 kelompok telur) }\end{array}$ & $\begin{array}{l}\text { Telenomus sp. } \\
\text { Telenomus sp. }\end{array}$ & $\begin{array}{r}100 \\
68\end{array}$ \\
\hline Pati $^{3}$ & $\begin{array}{l}\text { Chilo spp. }(\mathrm{n}=3 \text { kelompok telur }) \\
\text { S. excerptalis }(\mathrm{n}=3 \text { kelompok telur })\end{array}$ & $\begin{array}{l}\text { Telenomus sp. } \\
\text { Telenomus sp. }\end{array}$ & $\begin{array}{r}100 \\
68\end{array}$ \\
\hline Malang $^{3}$ & $\begin{array}{l}\text { Chilo spp. }(\mathrm{n}=64 \text { kelompok telur }) \\
\text { S. excerptalis }(\mathrm{n}=98 \text { kelompok telur) }\end{array}$ & $\begin{array}{l}\text { T. chilonis } \\
\text { Telenomus sp. } \\
\text { Telenomus } \mathrm{sp} .\end{array}$ & $\begin{array}{r}25 \\
43 \\
100\end{array}$ \\
\hline
\end{tabular}

${ }^{1}$ Pertanaman tebu dengan pelepasan T. chilonis.

${ }^{2}$ Pertanaman tebu tanpa pelepasan T. japonicum.

${ }^{3}$ Pertanaman tebu tanpa pelepasan Trichogramma.

dengan oleh T. chilonis, walaupun pada pertanaman tebu dengan pelepasan T. chilonis. Trichogramma spp. tidak memarasit telur penggerek pucuk, S. excerptalis, tetapi telur penggerek pucuk tersebut diparasit oleh Telenomus sp. Tingkat parasitisasi telur penggerek batang Chilo spp. lebih rendah dibandingkan dengan parasitiasi telur S. excerptalis.

Persentase kerusakan ruas tebu oleh penggerek batang Chilo sp. pada pertanaman dengan pelepasan Trichogramma spp. lebih tinggi dibandingkan dengan pada pertanaman tanpa pelepasan Trichogramma spp. (Tabel4). Persentase kerusakan batang bagian atas pada umumnya lebih tinggi dibandingkan dengan kerusakan batang bagian tengah dan bawah. Tingkat kerusakan batang tanaman baru (PC) di lokasi Situbondo yang mempunyai iklim kering relatif lebih tinggi dibandingkan dengan pada tanaman ratoon $(\mathrm{RC})$, sedangkan di lokasi Malang dan Pati masingmasing pada pertanaman baru dan ratoon tapa pelepaan Trichogramma, tingkat kerusakan batang relatif rendah.

\section{Keragaan reproduksi dan kebugaran Tricho- gramma spp.}

Sampel T. chilonis yang diperbanyak dengan C. cephalonica dan dari populasi alam di Lampung Tengah dan Situbondo laju reproduksinya $\left(R_{o}\right)$ lebih tinggi dibandingkan dengan spesies lain atau spesies yang sama dari Pati (Tabel 5). Nilai $\mathrm{R}_{\mathrm{o}}$ yang lebih tinggi menunjukkan bahwa pertumbuhan populasi betina T. chilonis lebih tinggi dibandingkan dengan $T$. japonicum, dan $T$. nana. Selain itu, T. chilonis juga menunjukkan kapasitas pertambahan populasi yang tinggi 
Tabel 4. Persentase ruas batang terserang pada pertanaman tebu dengan dan tanpa pelepasan Trichogramma spp.

\begin{tabular}{|c|c|c|c|c|}
\hline \multirow{2}{*}{ Lokasi } & \multirow{2}{*}{ Kondisi pertanaman tebu } & \multicolumn{3}{|c|}{$\%$ ruas terserang pada batang } \\
\hline & & atas & tengah & bawah \\
\hline$\overline{\text { Pati }}$ & $\begin{array}{l}\text { Tanaman pertama (PC), tebu rakyat, tanpa pelepasan } \\
\text { Trichogramma spp. }\end{array}$ & 1,3 & 0,3 & 0,0 \\
\hline Situbondo & $\begin{array}{l}\text { Tanaman ratoon kedua ( } \mathrm{RC} 2) \text {, tebu rakyat, tanpa pelepasan } \\
\text { Trichogramma spp. }\end{array}$ & 9,5 & 8,0 & 0,0 \\
\hline Situbondo & $\begin{array}{l}\text { Tanaman pertama (PC), tebu perkebunan besar, dengan } \\
\text { pelepasan Trichogramma japonicum }\end{array}$ & 47,9 & 49,3 & 14,3 \\
\hline Malang & $\begin{array}{l}\text { Tanaman ratoon ketiga ( } \mathrm{RC} 3 \text { ), tebu rakyat, tanpa pelepasan } \\
\text { Trichogramma } \mathrm{spp} \text {. }\end{array}$ & 0,0 & 0,0 & 0,0 \\
\hline
\end{tabular}

Tabel 5. Laju reproduksi Trichogramma spp. yang diperoleh dari unit produksi Trichogramma di Pabrik Gula (PG) Lampung Tengah, Situbindo, Pati, dan Malang

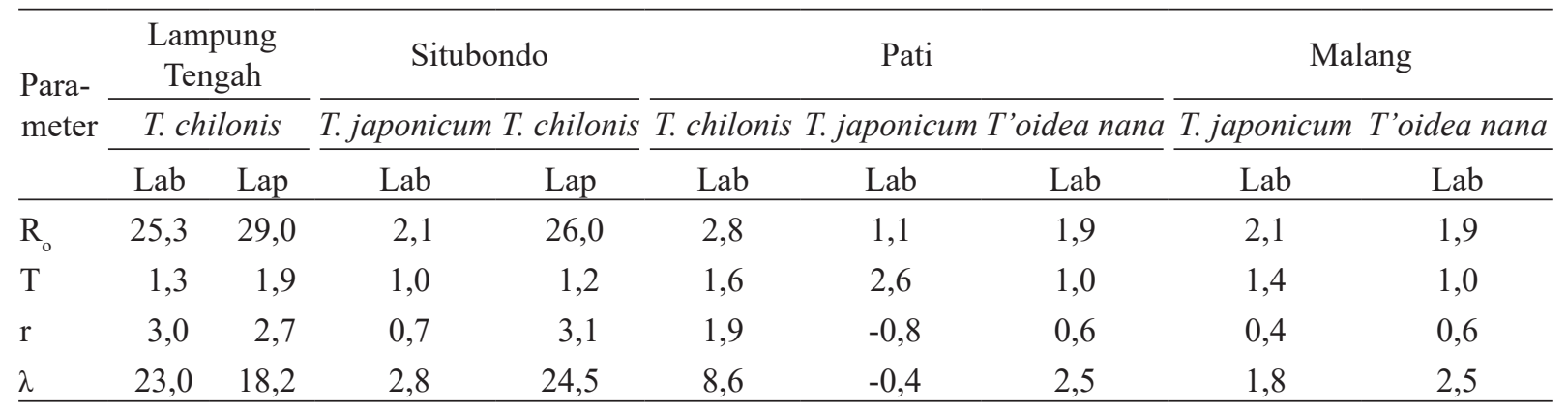

$\mathrm{R}_{0}$ : Laju reproduksi bersih (laju perkembangan populasi parasitoid per induk per generasi;

$\mathrm{T}$ : Waktu yang diperlukan parasitoid untuk menghasilkan satu generasi;

$\mathrm{r}$ : Kapasitas pertambahan populasi parasitoid;

$\lambda$ : Laju pertambahan parasitoid per hari;

Lab: Induk yang digunakan merupakan individu dari unit produksi yang diperbanyak di laboratorium dengan menggunakan telur Chilo cephalonica;

Lap: Induk yang digunakan merupakan individu yang muncul dari telur Chilo sp. yang terparasit di lapangan.

dibandingkan dengan spesies lainnya sehingga laju pertambahan populasinya per hari (1) juga lebih tinggi. Waktu yang diperlukan oleh induk Trichogramma spp. untuk menghasilkan satu generasi $(\mathrm{T})$ pada umumnya berkisar antara $1-2$ hari.

\section{PEMBAHASAN}

Parasitisasi telur kompleks penggerek (pucuk dan batang) tebu pada pertanaman dengan dan tanpa pelepasan Trichogramma spp. didominasi oleh Telenomus sp. Tingkat parasitisasi telur penggerek batang lebih rendah dibandingkan dengan tingkat parasitisasi penggerek pucuk. Tingkat parasitisasi telur penggerek pucuk dapat mencapai 100\% oleh Telenomus sp., baik pada pertanaman dengan pelepasan maupun tanpa pelepasan Trichogramma spp. Hal ini menunjukkan bahwa mortalitas telur penggerek pucuk bukan disebabkan oleh Trichogramma spp. yang dilepas, tetapi oleh Telenomus sp. yang secara alami terdapat dalam ekosistem pertanaman tebu. Kondisi ini juga merupakan konfirmasi dari pengamatan Mahrub (2000) yang melaporkan bahwa parasitisasi telur penggerek pucuk pada pertanaman tebu di Jawa pada umumnya oleh Tetrastichus schoenobii Ferriere dan Telenomus rowani Gahan dengan tingkat parasitisasi masing-masing sebesar 34,59\% dan 24,07\%. Selanjutnya, Meidalima (2014) melaporkan bahwa pada pertanaman tebu tanpa tumbuhan liar ditemukan 3 spesies parasitoid telur penggerek batang dan pucuk, yaitu Telenomus dignoides Nixon, Tetrastichus schoenobii Ferriere, dan T. chilonis dan pada pertanaman tebu dengan pelepasan T. chilonis tidak diperoleh parasitisasi telur penggerek pucuk. Dengan demikian, dapat dikonfirmasi lagi bahwa telur penggerek pucuk tebu S. excerptalis yang terdapat di Indonesia pada umumya diparasit oleh Telenomus sp. 
T. chilonis yang dilaporkan digunakan untuk mengendalikan kompleks penggerek tebu Scirpophaga nivella F., Chilo infuscatellus Snellen, Emmalocera depressella Swin, dan Acigona steniella (Hampson) dengan dosis pelepasan 150.000-300.000 parasitoid/acre dapat menurunkan kerusakan penggerek 35-43\% dibandingkan dengan kontrol (Nadeem \& Hamed 2011). Dalam penelitian ini, efektivitas T. chilonis dalam menyebabkan mortalitas penggerek pucuk tidak dapat diukur secara langsung, misalnya dengan menghitung mortalitas telur akibat adanya parasitisasi, tetapi secara tidak langsung dengan mengamati gejala kerusakan yang ditimbulkan oleh kompleks penggerek tebu. Selain itu, pada pertanaman tebu di Tamil Nadu, India, dilaporkan parasitisasi telur penggerek pucuk tebu (S. excerptalis) pada umumnya oleh T. chilonis dan Telenomus beneficiens (Zehntner) (Rajendran \& Giridharan 2003). Dengan demikian, peran dari T. chilonis, baik dari populasi yang dilepas maupun populasi alami, dalam menekan populasi penggerek pucuk $S$. excerptalis masih belum jelas. Oleh karena itu, teknik pengendalian penggerek pucuk tebu yang dilakukan di Indonesia dengan pelepasan Trichogramma spp. perlu dipertimbangkan lagi.

Parasitisasi telur penggerek batang tebu Chilo spp. pada pertanaman tebu di Lampung Tengah, Situbondo, dan Malang juga didominasi oleh Telenomus sp. (Tabel 3). Dari ketiga lokasi tersebut, tingkat parasitisasi telur Chilo spp. oleh T. chilonis pada umumnya lebih rendah dibandingkan dengan tingkat parasitisasi oleh Telenomus sp. Parasitisasi telur penggerek batang oleh $T$. chilonis hanya ditemukan pada petanaman tebu dengan pelepasan parasitoid tersebut (Tabel 3). Selanjutnya, tingkat kerusakan ruas tebu oleh penggerek batang pada pertanaman tebu dengan pelepasan $T$. japonicum relatif lebih tinggi dibandingkan dengan tingkat kerusakan pada pertanaman tebu tanpa pelepasan parasitoid (Tabel 4). Selain itu, T. japonicum yang dilepas pada pertanaman tebu di Situbondo tidak menyebabkan parasitisasi telur penggerek batang tebu karena spesies parasitoid yang memarasit telur penggerek batang tebu di lokasi ini adalah T. chilonis (Tabel 3). Kenyataan ini menunjukkan bahwa pelepasan T. japonicum belum menunjukkan efektivitasnya yang nyata dalam menyebabkan mortalitas telur penggerek batang tebu, Chilo spp. Lebih jauh,
Saeroji (2012) melaporkan bahwa pada pertanaman tebu PT Gunung Madu Plantation (GMP) di Lampung Tengah yang dilakukan pelepasan massal T. chilonis, parasitisasi telur C. auricilius oleh $T$. chilonis lebih tinggi dibandingkan dengan parasitisasi pada telur C. sacchariphagus ( $86 \%$ vs $55 \%$ ), dan telur penggerek pucuk $S$. excerptalis tidak pernah ditemukan terparasit oleh $T$. chilonis. Parasitisasi telur penggerek batang oleh $T$. chilonis pada pertanaman tebu PT GMP ini juga tidak diketahui apakah oleh parasitoid yang dilepas atau oleh spesies parasitoid dari populasi alami.

Parasitoid telur Trichogramma spp. yang dilepas untuk menekan populasi kompleks penggerek tebu yang dilakukan di Indonesia belum menunjukkan efektivitasnya yang nyata dibandingkan dengan yang dilakukan di Pakistan (Zia-ul-Hussnain et al. 2007; Ullah et al. 2012; Muhammad et al. 2012), dan India (lihat Khan \& Alam 2001). Hal ini dapat disebabkan oleh beberapa faktor, diantaranya adalah spesies dan kualitas parasitoid. Dari hasil pengamatan parsitisasi kompleks peng-gerek tebu yang tersaji pada Tabel 3 dapat dilihat bahwa spesies T. chilonis dan T. japonicum yang dilepas secara massal dengan dosis 100.000 ekor/ha/pelepasan pada 1,53,5 bulan dan interval pelepasan setiap minggu (8 kali pelepasan/musim) belum menyebabkan mortalitas telur yang nyata dibandingkan dengan mortalitas telur oleh parasitoid telur spesies lain, yaitu Telenomus sp. Sementara itu, T. chilonis yang diintroduksi dari Jawa untuk digunakan dalam pengendalian C. sacchariphagus di Reunion Island dengan dosis pelepasan T. chilonis 200.000/ ha/2 minggu untuk tanaman berumur 1-4 bulan pada 50 stasiun pelepasan/ha dilaporkan berhasil menekan kehilangan hasil oleh penggerek tebu 15-20\% (Goebel et al. 2010). Akan tetapi, dalam laporan Goebel et al. (2010) tersebut efektivitas T. chilonis dalam menimbulkan mortalitas telur C. sacchariphagus tidak diketahui dengan jelas karena predator, terutama semut, juga memberikan kontribusi yang nyata terhadap mortalitas penggerek tebu. Dengan demikian, efektivitas $T$. chilonis sebagai agens hayati penggerek batang tebu masih belum jelas kontribusinya dalam menekan populasi Chilo spp.

Dari sisi kualitas Trichogramma spp. yang digunakan dalam pengendalian kompleks penggerek tebu melalui pelepasan massal terlihat bahwa 
T. japoncum dan T'oidea nana menunjukkan keragaan reproduksi yang lebih rendah kualitasnya dibandingkan dengan $T$. chilonis (Tabel 5). Hal ini menunjukkan bahwa $T$. japoncum dan T'oidea nana kurang sesuai untuk digunakan dalam pengendalian kompleks penggerek tebu dibandingkan dengan T. chilonis. Walaupun demikian, Sudarsono (2011) melaporkan bahwa T. chilonis yang diperbanyak di Laboratorium pada generasi ke-9 menurun kemampuannya secara nyata dalam memarasit telur $C$. auricilius. Kegagalan pengendalian penggerek batang tebu dengan pelepasan Trichogramma disebabkan kurangnya pemahaman tentang spesies parasitoid yang digunakan dalam program pengendalian, termasuk pemahaman bionomik, serta metode efikasinya dan quality control dalam produksi massal (Goebel et al. 2010). Oleh karena itu, pemilihan kandidat agens hayati untuk pengendalian hayati dengan pelepasan massal hendaknya dilakukan dengan melalui seleksi yang meliputi bioekologi parasitoid yang meliputi kesesuaian inang sasaran serta interaksi inter dan intra spesies yang terdapat dalam satu ekosistem (Andrade et al. 2011; Romeis et al. 2005; Steidle et al. 2001). Pengendalian hayati penggerek tebu di Brazil dinyatakan berhasil (mampu menekan populasi penggerek hingga 60,2\%) dengan melepas parasitoid telur T. galloi dan parasitoid larva $C$. flavipes setelah dilakukan penelitian selama 20 tahun (Parra \& Zucchi 2004).

Pengendalian kompleks penggerek tebu dengan melepas Trichogramma spp. yang selama ini dilakukan di Indonesia perlu dievaluasi lebih lanjut sehingga didapatkan praktek pengendalian hayati dengan teknik augmentasi parasitoid telur yang efektif dan efisien. Evaluasi lanjut yang perlu dilakukan adalah pemilihan spesies kandidat parasitoid yang tepat sehingga dapat efektif memberikan sumbangan mortalitas yang nyata terhadap serangga hama sasaran. Selain itu, dinamika populasi serangga hama sasaran pada suatu ekosistem hendaknya telah dipahami benar sehingga dapat menerapkan teknik pengendalian yang efektif dengan menyesuaikan waktu pelepasan dan keberadaan inang di pertanaman, serta jumlah parasitoid yang dilepas.

\section{KESIMPULAN}

Pelepasan Trichogramma spp. belum menunjukkan hasil yang nyata dalam menyebabkan mortalitas telur penggerek pucuk dan penggerek batang tebu. T. japonicum yang digunakan sebagai agens hayati dalam pelepasan massal tidak pernah ditemukan memarasit telur penggerek pucuk dan penggerek batang tebu. T. chilonis yang juga dilepas massal tidak menyebabkan parasitisasi pada telur penggerek pucuk, sedangkan efektivitasnya dalam menyebabkan mortalitas pada telur penggerek batang masih belum jelas karena populasi $T$. chilonis alami juga berperan dalam menyebabkan mortalitas telur penggerek batang tebu. Parasitisasi telur penggerek pucuk dan penggerek batang tebu secara alami didominasi oleh Telenomus spp.

\section{UCAPAN TERIMA KASIH}

Penulis menyampaikan terima kasih kepada para pengelola unit produksi Trichogramma di PG Krebet, Malang; PG Asembagus, Situbondo; PG Trangkil, Pati; dan PT GMP, Lampung Tengah, yang telah memberikan sampel Trichogramma spp. dari unit produksinya untuk dievaluasi kebugarannya. Sumber dana Penelitian ini adalah dari DIPA Balittas TA 2013.

\section{DAFTAR PUSTAKA}

Achadian EM, Kristini A, Margarey RC, Sallam N, Samson P, Goebel F-R, Lonie K. 2011. Hama dan Penyakit Tebu. Jakarta: P3GI, BSES \& ACIAR. Afghan S, Hussnain Z, Hussnain K, Naheed A, Rizwana S. 2006. Biocontrol of insect pests of sugarcane (Saccharum sp.). In: Proceedings of 41th Annual Convention (21-22 August 2006). pp. 109-119. Rwalpindi: Pakistan Society of Sugar Technologists.

Andrade GS, Pratissoli D, Dalvi LP, Desneux N, Dos Santos HJG Jr. 2011. Performance of four Trichogramma species (Hymenoptera: Trichogrammatidae) as biocontrol agents of Heliothis virescens (Lepidoptera: Noctuidae) under various temperature regimes. Journal of Pest Science 84:313-320. doi: https://doi. org/10.1007/s10340-011-0364-3. 
Bhati IB, Panwar DB, Chohan M, Unar GS. 2008. Incidence and intensity of borer complex infestation on different sugarcane varieties under agro-climatic conditions of Thatta. Journal of Pakistan Science 60:103-106.

Birch LC. 1948. The intrinsic rate of natural increase of an insect population. Journal of Animal Ecology 17:15-26. doi: https://doi.org/10.2307/ 1605.

Box HE. 1953. List of Sugar-Cane Insects. London: Commonwealth Institute of Entomology.

Chi H. 1988. Life-table analysis incorporating both sexes and variable development rates among individuals. Environmental Entomology 17:2634. doi: https://doi.org/10.1093/ee/17.1.26.

Dias-pini NS, Maria S, Broglio F, Costa S, Maria J, Guzzo EC. 2012. Biological characteristics of Telenomus alecto and Trichogramma galloi reared on eggs of the sugarcane borer Diatraea flavipennella. Revista Brasileira de Entomologia 56:515-518. doi: https://doi.org/10.1590/S008556262012000400020.

Ganeshan S, Rajabalee A. 1997. Parasitoids of the sugar cane spotted borer, Chilo sacchariphagus (Lepidoptera: Pyralidae), in Mauritius. Proceedings of the South African Sugar Cane Technologists'Association 71:87-90.

Goebel ER, Marquier M, Frandon J, Thi Khanh HD, Tabone E. 2010. Biocontrol of Chilo sacchariphagus (Lepidoptera: Crambidae) a key pest of sugarcane: Lessons from the past and future prospects. Sugar Cane International 28: 128-132. doi: https://doi.org/10.1016/j.cosust. 2010.12.005.

Goebel F, Sallam N. 2011. New pest threats for sugarcane in the new bioeconomy and how to manage them. Current Opinion in Environmental Sustainability 3:81-89.

Gul F, Naeem M, Inayatullah. 2008. Effect of different control methods on the infestation of borers in sugarcane plant and ratoon crops. Sarhad Journal of Agriculture 24:273-278.

Hadisaputro S. 2011. Sambutan Direktur Pusat Penelitian Perkebunan Gula Indonesia (P3GI) Pasuruan, Workshop Pengendalian Hama Terpadu Pada Tanaman Tebu Guna mendukung Kinerja Industri Gula, Pasuruan, 19 Juli 2011. Tersedia di: http://www.antarajatim.com/lihat/ berita/67094/penggerek-masih-menjadi-hamautama-tebu [diakses pada 2 Oktober 2015].

Javier PA, Gonzales PG. 2000. Management of Sugarcane Borer Using Trichogramma chilonis. Leaflet No. 6, Philippine Sugar Research Institute.
Khan, KA, Alam MM. 2001. Some facts regarding the use of Trichogramma against the sugarcane borers. Proceedings of 36th Annual Convention of Pakistan Society of Sugar Technologist 1:103107.

Liu FH, Smith SM. 2000. Measurement and selection of parasitoid quality for massreared Trichogramma minutumI Riley used in inundative release. Biocontrol Science and Technology 10:3-13. doi: https://doi.org/10.1080/09583150029332.

Magarey RC, Kristini A, Sallam N, Samson PR, Achadian E, McGuire PJ, Goebel R, Lonie KJ. 2010. IPM strategies for pest and disease control in Indonesia: Project overview and outcomes from recent aciar-funded research. Proceedings of the Australian Society of Sugar Cane Technologists 32:169-180.

Mahrub E. 2000. Evaluasi potensi parasitoid penggerek pucuk tebu, di Kabupaten Bantul. Jurnal Perlindungan Tanaman Indonesia 4:142-148.

Marquier M, Roux E, Tabone E, Goebel R. 2008. Lutte biologique contre le foreur ponctué de la canne à sucre à l'île de la Réunion: réduction de la densité et de la fréquence des lâchers du parasitoïde Trichogramma chilonis Ishii; In: Colloque Biodiversité et Changements climatiques et 8ème Conférence Internationale sur les. Ravageurs en Agriculture (Montpellier, 21-23 October 2008). pp. 427-435. Paris : AFPP.

Meidalima D. 2014. Parasitoid hama penggerek batang dan pucuk tebu di Cinta Manis, Ogan Ilir Sumatera Selatan. Biosaintifika 6:1-7.

Mohyuddin AI. 1992. Implementation of integrated pest management of sugarcane pests in Pakistan. In: Ooi PAC, Lim GS, Ho TH, Manalo PL, Waage JK (Eds.) Integated Pest Management in the AsiaPacific region (Kuala Lumpur, 23-27 September 1991). pp.73-84 . UK: CAB International.

Muhammad R, Rustamani MA, Suleman N, Ahmad N, Ahmad Q. 2012. Impact of release intervals and densities of Trichogramma chilonis (Ishii) (Hymenoptera: Trichogrammatidae) against the sugarcane stem borer, Chilo infuscatellus (Lepidoptera: Pyralidae) under field conditions. Journal of Basic \& Applied Sciences 8:472-477. doi: https://doi.org/10.6000/1927-5129.2012.08. 02.36 .

Nadeem S, Hamed M. 2011. Biological control of sugarcane borers with inundative release of Trichogramma chilonis (Ishii ) ( Hymenoptera: Trichogrammatidae) in farmer fields. Pakistan Journal of Agricultural Science 48:61-64.

Naqvi KM, Siddiqui AR, Jaffery MA, Lodhi MR. 1978. Effect of borer infestation on quality and 
quantity of sugarcane. Journal of Agricultural Resesearch 16:369-378.

Nurindah. 2004. Teknik Perbanyakan Trichogramma. Monograf Balittas No. 7, Kapas Buku 2. p: 178 186. Malang: Balittas.

Parra JRP, Zucchi RA, 2004. Trichogramma in Brazil: feasibility of use after twenty years of research. Neotropical Entomology 33:271-281. https:// doi.org/10.1590/S1519-566X2004000300001.

Pramono D, Hermawan R, Sulistyana MM, Mudakir, Harianto. 2006. Pelaksanaan \& Manfaat Program Early Warning System (EWS) di Kawasan PG Bungamayang-Lampung, PTPN VII Persero Periode tanam 2006/2007-2008/2009. Lampung: Litbang UU, Bungamayang, PTPN VII Persero.

Purwono. 2012. Budi daya Tanaman Tebu. Di dalam: Workshop Budidaya Tebu dan Pemanfaatan Limbah Sebagai Pupuk Organik (Malang, 2324 November 2012). Malang: Balai Penelitian Tanaman Pemanis dan Serat

Rajendran B, Giridharan S. 2003. Incidence of sugarcane top borer and its natural field parasitisation. India Sugar 53:37-39.

Romeis J, Babendreier D, Wäckers FL, Shanower TG. 2005. Habitat and plant specificity of Trichogramma egg parasitoids-underlying mechanisms and implications. Basic and Applied Ecology 6:215-236. doi: https://doi.org/10.1016/ j.baae.2004.10.004.

Reagan TE. 2001. Integrated pest management in sugarcane. LA Agric 44:16-18.

Saeroji S, Sunaryo, Gunito H. 2010. The effect of bagasse furnace ash application on sugarcane resistance to top borer Scirpophaga nivella intacta Snellen (Lepidoptera: Pyralidae). Proceedings International Society Sugar Cane Technologist 27:1-6.

Sallam N, Achadian E, Kristini A, Sochib M, Adi H. 2010. Monitoring sugarcane moth borers in indonesia: towards better preparedness for exotic incursions. Proceedings Australian Society of Sugar Cane Technology 32:181-192.
Soma AG, Ganeshan S. 1998. Status of the sugarcane spotted borer, Chilo sacchariphagus Bojer (Lepidoptera: Pyralidae: Crambinae) in Mauritius. Food and Agricultural Research Council, Réduit, Mauritius, AMAS 1998:111-117.

Steidle JLM, Rees D, Wrigth EJ. 2001. Assessment of Australian Trichogramma species (Hymenoptera: Trichogrammatidae) as control agents of stored product moths. Journal of Stored Products Research 37:263-275. doi: https://doi. org/10.1016/S0022-474X(00)00027-8.

Suasa-ard W. 2010. Natural enemies of important insect pests of field crops and utilization as biological control agents in Thailand. In: Proceedings of International Seminar on Enhancement of Functional Biodiversity Relevant to Sustainable Food Production in ASPAC - In association with MARCO (Tsukuba, 9-11 November 2010). pp. 1-15. Tsukuba: National Institute for Agro-Environtmental Science.

Sudarsono H. 2011. Kajian beberapa karakteristik biologi penggerek batang tebu berkilat Chilo auricilius dan parasitoidnya (Trichogramma chilonis). Di dalam: Prosiding Seminar Hasil Penelitian \& Pengabdian Kepada Masyarakat (Lampung, 21 September 2011). hlm. 33-39. Lampung: Universitas Lampung.

Ullah F, Shakur M, Badshah H, Ahmad S, Amin M, Zamin M. 2012. Efficacy of Trichogramma chilonis Ishii in comparison with two commonly used insecticides against sugarcane stem borer Chilo infuscatellus Snellen (Lepidoptera: pyralidae). Jurnal of Animal and Plant Science 22:463-466.

Zia-ul-Hussnain, Naheed A, Rizwana S. 2007. Biocontrol of insect pests of sugarcane (Saccharum sp.). Pakistan Sugar Jurnal 22:1423. 